\title{
Influences of special driving situations on emissions of passenger cars
}

Testing of real driving emissions (RDE) offers the opportunity to collect the data about the emissions in special driving, or nondriving situations. These situations are: cold start, warm-up of the engine, stop \& go and idling. In the present work, the definitions of the special driving situations were proposed, the emissions of 7 passenger cars (gasoline \& Diesel) were extracted from the present RDE data and some special driving situations, particularly the stop \& go operation with varying share of idling were reproduced on chassis dynamometer. As expected, the emissions of $C O, N O_{x}$ and PN are in the cold start and in the first part of the warm-up phase (ca. $25 \mathrm{~s}$ ) considerably higher than in the rest of the investigated urban phase. The singular emitting situations like "stop\&go" or idling occur frequently in the warm-up phase, i.e. in the city operation when the engine and the exhaust system are still not warm enough.

Key words: emissions at cold start, warm-up, RDE, portion of idling, stop\&go

\section{Introduction}

Emission factors and emission inventories are an important source of data for compiling and modelling the emissions of traffic in different situations. There is in EU a continuous work and development of emission data inventories [1-6].

Since the introduction (in 2017) of the road-testing (RDE - real driving emissions) as an obligatory element of the legal testing procedures, the increased amount of RDEdata can be used for different objectives, such as: further development of emission inventories, compliance with "InService Conformity" (ISC, EU regulation 2018/1832) and market surveillance activities (EU regulation 2018/858). Extensive activities of testing RDE by means of PEMS (portable emissions measuring systems) have been performed in the last years, aiming not only the emissions but also the improvements of instrumentation, of testing procedures and of evaluation [5-17].

A well-known fact is that the emissions at cold start, during the warm-up and at the low speed phases of urban operation, both in the laboratory and on the road, tend to be higher for all pollutants [13, 18-24]. This fact supports even the idea for future introduction of urban emission limits for the short trips, which are very frequent in Europe [5].

In order to enable an automatic co-evaluation of emissions from the special (non)driving situations, the necessary definitions were proposed in the present work. With these definitions, the RDE data of 7 vehicles were processed and the emissions in special driving situations were obtained (part 1). Additionally, some special situations like cold start, warm-up and stop\&go were reproduced on the chassis dynamometer with cars of different ages and different technology (part 2).

This paper gives some new insights in the topic of emissions from special driving situations.

\section{Analysis of present RDE data (part 1)}

\subsection{Data origin \& processing}

The emissions data originate from testing of different vehicles with Horiba PEMS (Portable Emission Measuring
Systems for gaseous emissions) and with PN-PEMS (for particle number $\mathrm{PN}$ ) at $\mathrm{AFHB}$.

The Horiba OBS-ONE-PN PEMS uses two-step dilution, a catalytic volatile particle remover $\left(350^{\circ} \mathrm{C}\right)$ and an Isopropanol-based CPC as a main measuring unit.

Figure 1 represents the PEMS installation on a vehicle.

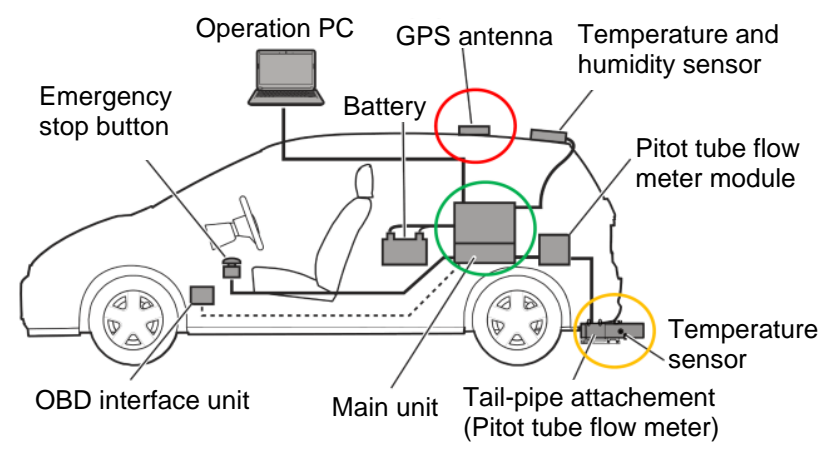

Concentrations, Mass Flow, Distance $\Rightarrow \mathrm{g} / \mathrm{km}$

Fig. 1. Set-up of PEMS on a vehicle

The results of exhaust gas measuring devices are given as volume concentrations. Nevertheless, the legal limits are expressed in $[\mathrm{g} / \mathrm{km}]$ for $\mathrm{LDV}$, or in $[\mathrm{g} / \mathrm{kWh}]$ for HDV.

Therefore, it is necessary to install a flowmeter at the tailpipe of the vehicle and to estimate the instantaneous exhaust gas mass flow in the transient operation.

In the data processing, the vehicle positions and speeds are required. They are usually registered from the GPS (Global Positioning System), which is installed on the vehicle. If this signal is not available, e.g. in the tunnel, the speed can be obtained from the OBD-interface (on Board Diagnose) of the vehicle.

Additionally, the parameters such as the engine coolant temperature and the engine speed are registered by the OBD.

The pollutant components measured by both PEMS (Gas \& PN) are carbon dioxide $\mathrm{CO}_{2}$, carbon monoxide $\mathrm{CO}$, nitric oxides $\mathrm{NO}_{\mathrm{x}}$ (consisting of $\mathrm{NO}$ and $\mathrm{NO}_{2}$ ) and particle number $\mathrm{PN}$ (considering the invisible nanoaerosol). 
For the choice of data (vehicles previously measured in other projects) following criteria were taken into consideration:

- Version of the RDE route,

- The same measuring system,

- Engine cold start measured,

- Engine start measured,

- Emission components measured $\left(\mathrm{CO}_{2}, \mathrm{CO}, \mathrm{NO}_{\mathrm{x}}, \mathrm{PN}, \mathrm{HC}\right)$,

- Start-stop-system (switched off).

Seven vehicles (three gasoline and four Diesel) could be chosen for the data evaluation. Table 1 summarizes the most important data of these vehicles.

Some criteria could not be completely fulfilled:

- Start-stop-system of LDV 07 was switched on,

- PN was not measured for some vehicles,

- HC was not measured for all vehicles.

Table 1. List of vehicles chosen for the data evaluation (LDV - light duty vehicle)

\begin{tabular}{|c|c|c|c|c|}
\hline No. & Fuel & $\begin{array}{c}\text { Displa- } \\
\text { cement }\end{array}$ & $\begin{array}{c}\text { Exhaust Aftertreatment } \\
\text { System }\end{array}$ & Injection \\
\hline LDV01 & Gasoline & 1.6 & TWC & PFI \\
\hline LDV02 & Gasoline & 4.0 & TWC, GPF & DI \\
\hline LDV03 & Gasoline & 6.2 & TWC & PFI \\
\hline LDV04 & Diesel & 2.0 & DOC, DPF & DI \\
\hline LDV05 & Diesel & 2.1 & DOC, DPF, SCR & DI \\
\hline LDV06 & Diesel & 3.0 & DOC, DPF, SCR & DI \\
\hline LDV07 & Diesel & 3.0 & DOC, DPF, SCR & DI \\
\hline
\end{tabular}

\subsection{Definitions of non-driving situations}

\section{Distance driven and urban part}

In the legal RDE-evaluation of LDV's the parts of driving, which were performed with the speed lower than 60 $\mathrm{km} / \mathrm{h}$, are considered as "urban", even if they were performed outside of the city. In opposition, the urban part in this work is defined as the first $13.7 \mathrm{~km}$ of the distance driven. This was decided after investigating the speeds, distances and emission traces of the chosen vehicles. 13.7 $\mathrm{km}$ is the shortest distance before one of the vehicles reached the speed of $60 \mathrm{~km} / \mathrm{h}$. With this definition of urban part, it is fixed that all investigated vehicles were driven below this speed limit value $(60 \mathrm{~km} / \mathrm{h})$. Furthermore, it was observed that during this $13.7 \mathrm{~km}$, there were the specific driving-and emissions-situations, which are the subject of this research: cold start, warm-up, stop\&go, idling.

The investigation of the high-speed driving parts - rural and highway - showed no noticeable emission events.

\section{Cold start}

The cold start is defined with the engine coolant temperature (ECT) as: $\left(\mathrm{ECT}+2^{\circ} \mathrm{C}\right)<\mathrm{t}_{\mathrm{amb}}$, or ECT $<30^{\circ} \mathrm{C}$. This means that ECT can be up to $2^{\circ} \mathrm{C}$ higher than the ambient temperature or it must be lower than $30^{\circ} \mathrm{C}$. This definition originating from the HDV-legislation is applied in this work because it is stricter than the definition from the LDV-legislation $\left(+7^{\circ} \mathrm{C}, 35^{\circ} \mathrm{C}\right)$.

\section{Engine warm-up}

The warm-up time is defined in two ways: a. from the engine start $(\mathrm{n}>500 \mathrm{rpm})$ to the instant of $\mathrm{ECT}=70^{\circ} \mathrm{C}-$ this is named: "ECT 70" and

b. from the engine start $(n>500 \mathrm{rpm})$ to the duration of 5 minutes - this is named: "5 minutes".

These definitions and examples of the warm-up for two vehicles (gasoline \& Diesel) are represented in Fig. 2. It can be clearly remarked that the Diesel vehicle needs a longer time to attain the ECT 70.

Figure 5 summarizes the time-traces of ECT for all investigated vehicles. For LDV1 and LDV5, there are some irregular increases of ECT. ECT of LDV1 reaches $70^{\circ} \mathrm{C}$ in approximately 4 minutes after start. However, it falls again below $70^{\circ} \mathrm{C}$ for approximately 1 minute. This 1 minute is accounted to the warm-up according to the definition.

For more detailed analyses it is useful to consider both warm-up definitions and the time-courses of the increasing ECT.
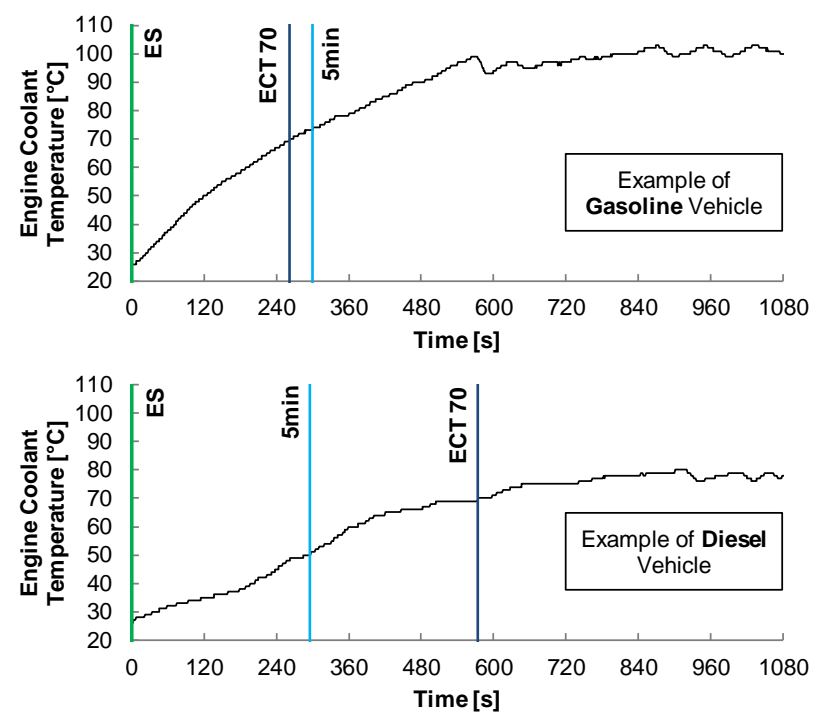

ES: Engine Start (Start of "Engine In Operation")

ECT 70: Engine Coolant Temperature (ECT) reaches $70^{\circ} \mathrm{C}$

$5 \mathrm{~min}: 5 \mathrm{~min}$ after Engine Cold Start

\begin{tabular}{|l|l|l|l|}
\hline Definitions & start & end \\
\hline Cold Start & state & ECT $<\mathrm{T}_{\text {ambient }}+2^{\circ} \mathrm{C}$ OR ECT $<30^{\circ} \mathrm{C}$ & - \\
\hline Engine in Operation & state & Engine Speed $>500 \mathrm{rpm}$ & - \\
\hline Warm-Up ECT 70 & phase & Cold Start AND Engine in Operation & ECT $>70^{\circ} \mathrm{C}$ \\
\hline Warm-Up 5min & phase & Cold Start AND Engine in Operation & Phase Time $>5 \mathrm{~min}$ \\
\hline
\end{tabular}

Fig. 2. Definition of warm-up in RDE-test

\section{Stop\&go}

According to ASTRA, the definitions of traffic congestion which are used for the public traffic information are:

- the traffic jam on the extra-urban route is given when the speed is below $10 \mathrm{~km} / \mathrm{h}$ during at least 1 minute and frequent standstill occurs,

- in the city circulation, the traffic jam is considered when the loss of summary time is over 5 minutes.

These definitions are close to the stop\&go operation and they gave the basis for the definition which is easy to understand and which depicts well this driving situation.

The operation of the vehicle with the driving speeds between $1 \mathrm{~km} / \mathrm{h}$ and $10 \mathrm{~km} / \mathrm{h}$ is considered as a "stop\&go" phase. In this way, the vehicle standstill (stop) and the short 
acceleration by moving (go) are included in this operation mode.

Figure 3 shows the definition and example of stop\&go in the urban part $(13.7 \mathrm{~km})$. Figure 5 summarizes the shares of stop\&go in the urban part for all investigated vehicles. These shares are in the range of $13 \%$ to $19 \%$.

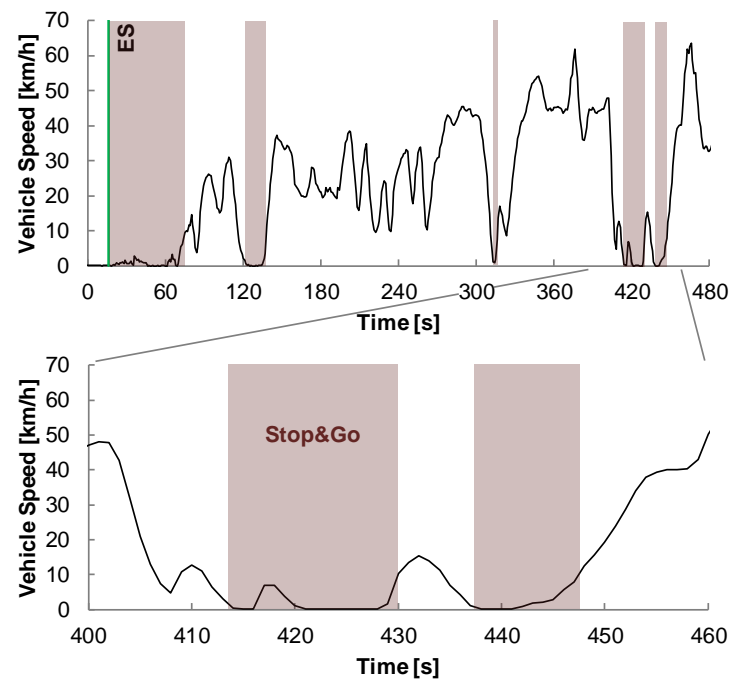

ES: Engine Start (Start of "Engine In Operation")

\begin{tabular}{|l|l|l|l|}
\hline Definition & start & end \\
\hline Stop\&Go & phase & Vehicle Speed $<1 \mathrm{~km} / \mathrm{h}$ & Vehicle Speed $>10 \mathrm{~km} / \mathrm{h}$ \\
\hline
\end{tabular}

Fig. 3. Definition of stop\&go in RDE-test

\section{Idling}

The idling phase is given, when the engine speed is between $500 \mathrm{rpm}$ and $900 \mathrm{rpm}$ and the vehicle speed is below $1 \mathrm{~km} / \mathrm{h}$.

Figure 4 shows the definition and example of idling in the urban part and Fig. 5 summarizes the shares of idling in the urban part for all investigated vehicles. These shares are in the range of $6 \%$ to $13 \%$.
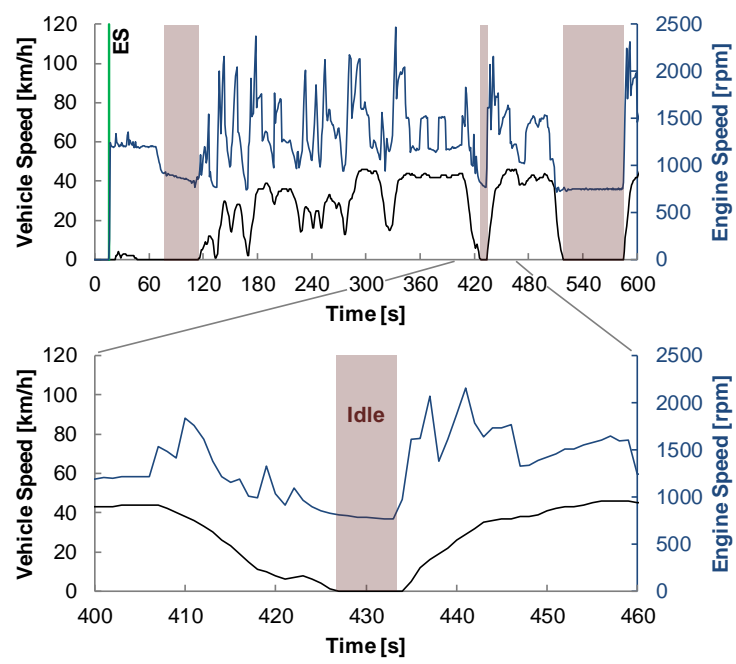

ES: Engine Start (Start of "Engine In Operation")

\begin{tabular}{|l|l|l|l|}
\hline Definition & start & end \\
\hline Idling & state & $500 \mathrm{rpm}<$ Engine Speed $<900 \mathrm{rpm}$ & - \\
\hline Idle & phase & Vehicle Speed $<1 \mathrm{~km} / \mathrm{h}$ AND Idling & Idle Start Cond. False \\
\hline
\end{tabular}

Fig. 4. Definition of idling in RDE-test
According to these definitions, there is a certain overlapping of the data of the considered non-driving situations, see Fig. 6.
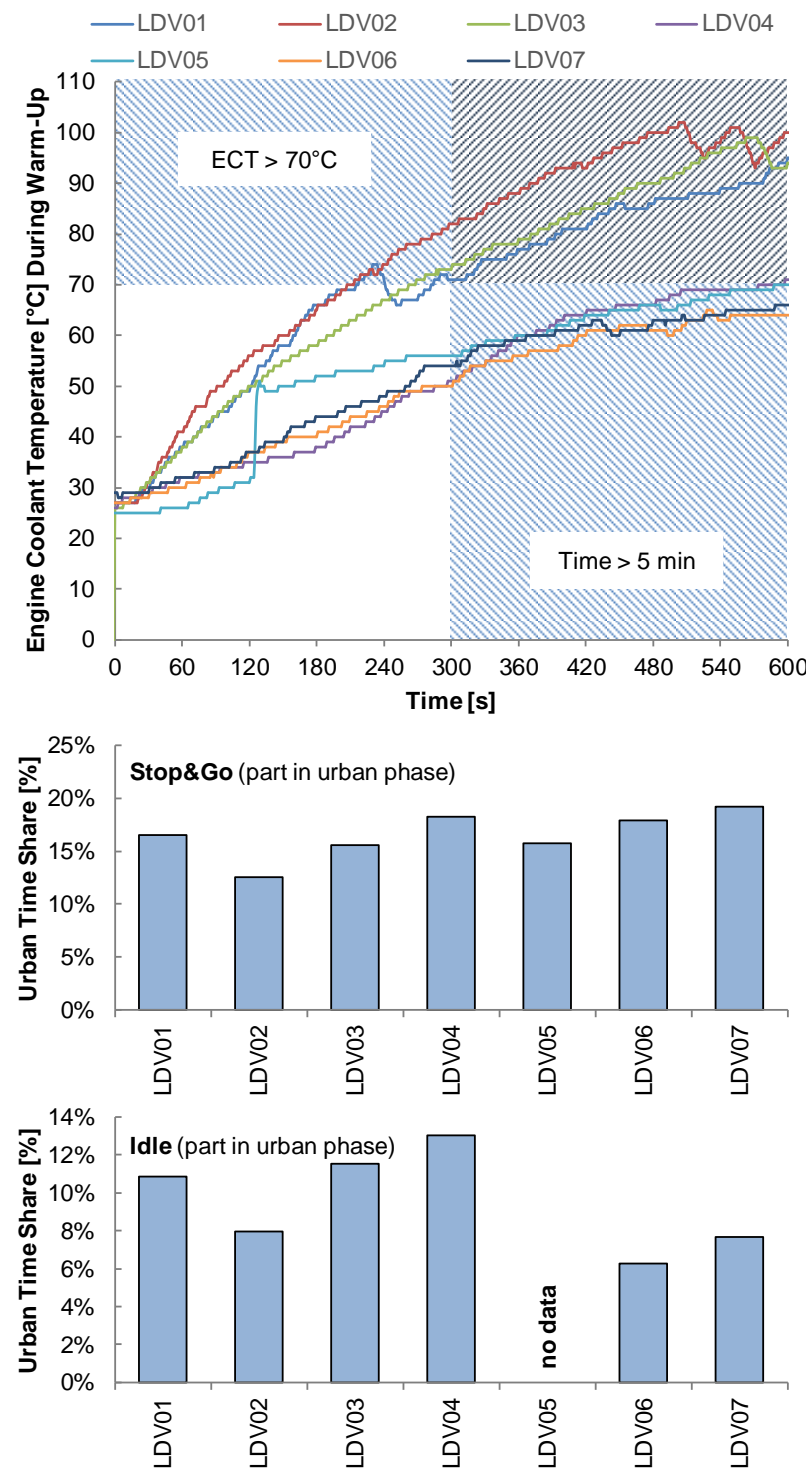

Fig. 5. Time courses of the engine coolant temperature during warm-up and time shares of stop\&go and idling in the RDE-test

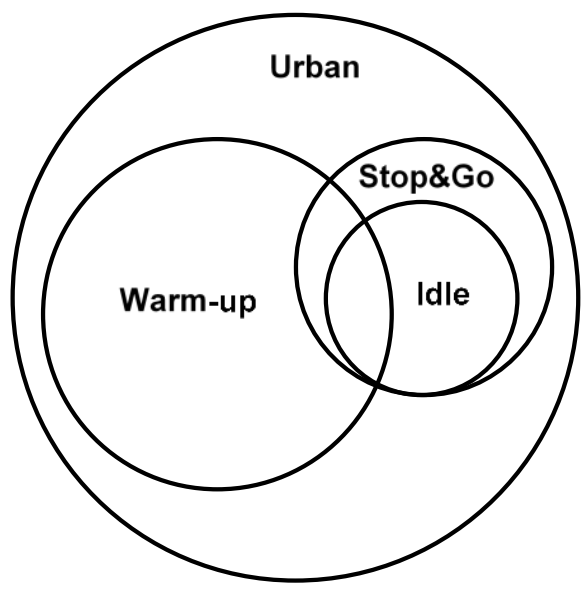

Fig. 6. Qualitative overlapping of the analyzed data 


\section{Results}

The evaluated emissions data are expressed as total cumulated values in $[\mathrm{g}],[\#]$, as emissions per time in $[\mathrm{g} / \mathrm{min}]$, $[\# / \mathrm{min}]$ or as specific emissions per distance $[\mathrm{g} / \mathrm{km}]$, $[\# / \mathrm{km}]$. The specific emissions (per $\mathrm{km}$ ) respond to the legal view, they are comparable with legal limit values, but they are not applicable for the non-driving situations, where the distance driven is zero (like idling or stop\&go). These facts are considered in the data representation.

\subsection{Warm-up}

Figure 7 represents the cumulative emissions over time during the urban phase $(13.7 \mathrm{~km})$ for the gasoline vehicles. Figure 8_shows the analogous results for Diesel vehicles. It can be remarked that for the gasoline vehicles (LDV1 LDV3), the ECT 70-warm-up happens earlier or simultaneously with the 5 minutes-point. For the Diesel vehicles (LDV4 - LDV7) inversely, the ECT 70-warm-up takes generally a longer time and it arrives after the 5 minutespoint.
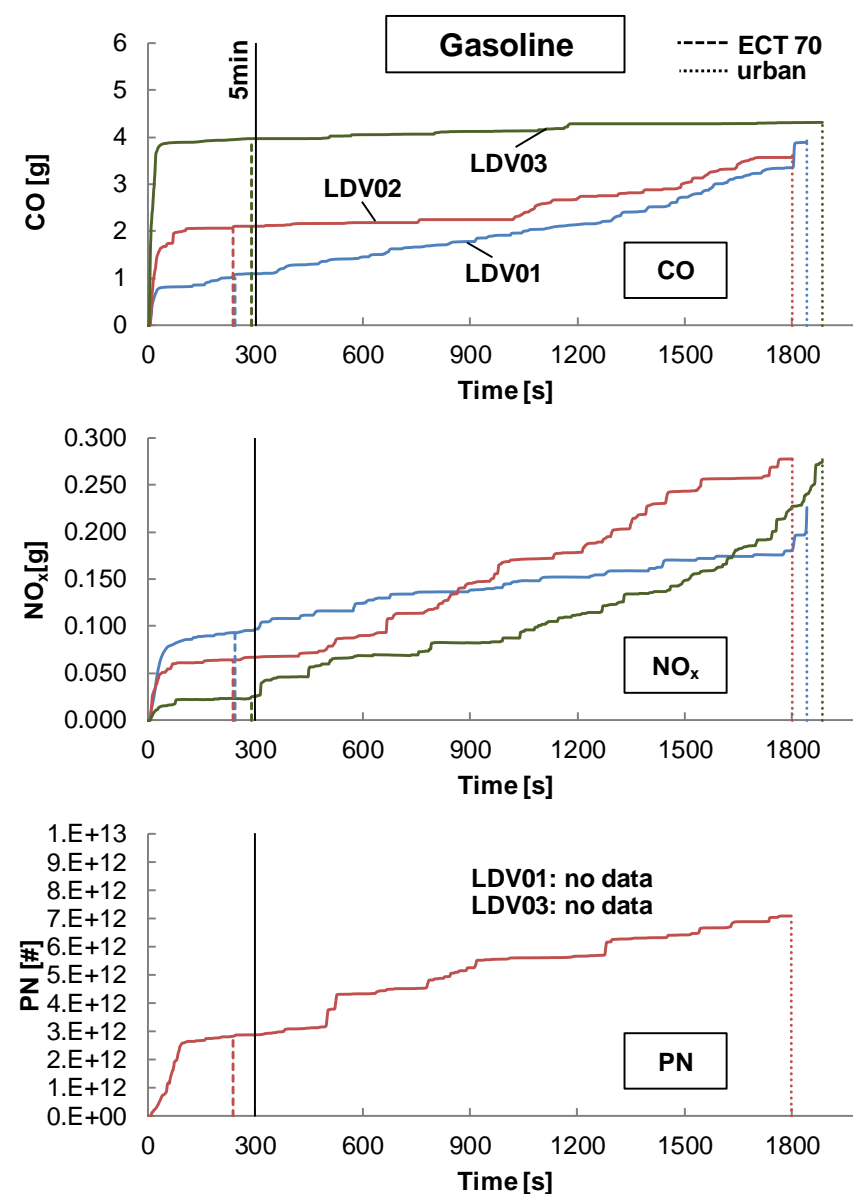

ECT 70: engine coolant temperature reaches $70^{\circ} \mathrm{C}$

5 min: 5 min after engine cold start

urban: part of RDE-Route (geographically defined distance: $13.7 \mathrm{~km}$ )

Fig. 7. Cumulated emissions of gasoline vehicles during the warm-up phase

From the comparison of vehicles, it can be stated, that:

- vehicles with smaller engine displacement produce lower $\mathrm{CO}_{2}$-emissions,
- most emissions of $\mathrm{CO}$ and $\mathrm{NO}_{\mathrm{x}}$, especially in the "gasoline" group are produced during and shortly after cold start,

- in both vehicles" groups: "gasoline" and "Diesel", there are quite considerable emissions differences between the vehicles, resulting mostly from different efficiencies of the exhaust aftertreatment systems,

- the urban phase $(13.7 \mathrm{~km})$ is driven by different vehicles at different time, due to different average speeds resulting from the traffic situations.

Specific emissions (per $\mathrm{km}$ ) and their increase factors in the warm-up phase are compared for all vehicles in the Fig. 9.

The $\mathrm{CO}[\mathrm{g} / \mathrm{km}]$ in warm-up are generally higher than in the entire urban phase $(13.7 \mathrm{~km})$. The "warm-up increase factor" varies between $2 \& 11$ for gasoline and $1 \& 4$ for Diesel vehicles. CO-values of LDV4 are particularly high indicating most probably some problems of engine, or of inactive DOC.
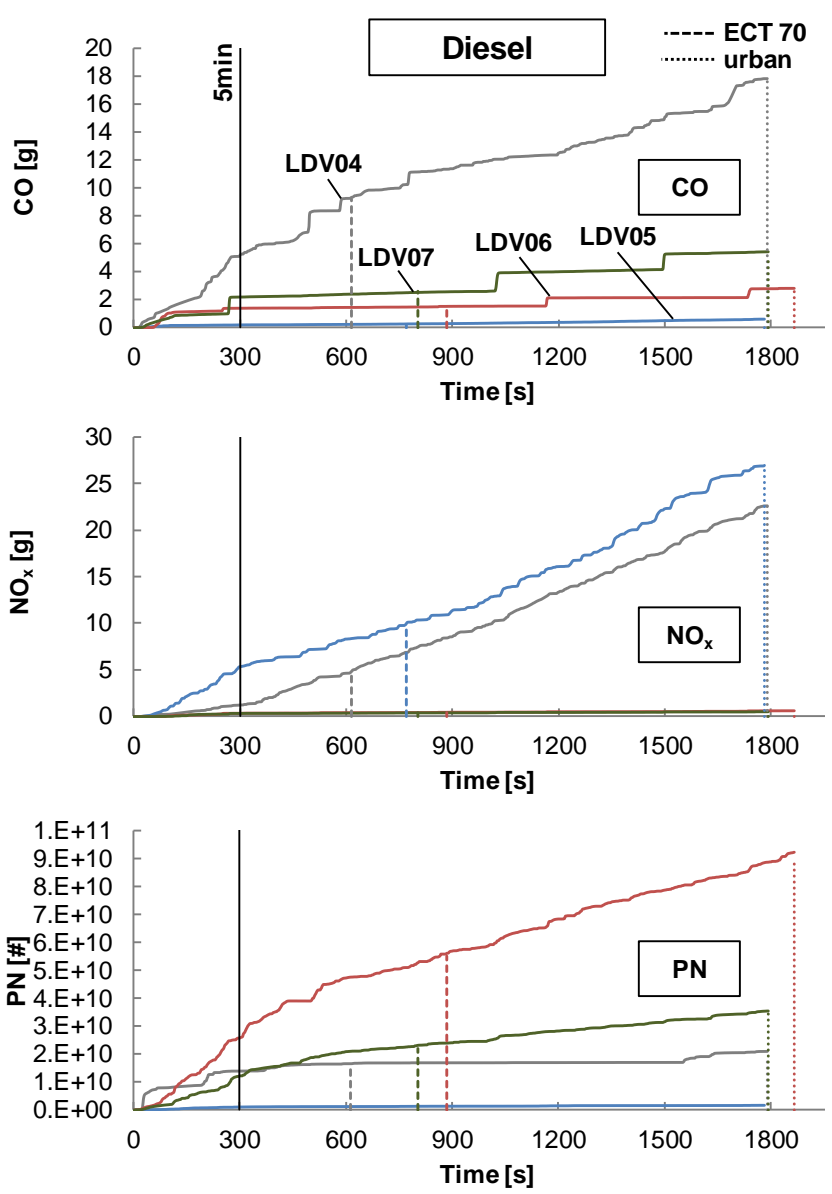

ECT 70: engine coolant temperature reaches $70^{\circ} \mathrm{C}$

5 min: 5 min after engine cold start

urban: part of RDE-Route (geographically defined distance: $13.7 \mathrm{~km}$ )

Fig. 8. Cumulated emissions of Diesel vehicles during the warm-up phase

The $\mathrm{NO}_{\mathrm{x}}[\mathrm{g} / \mathrm{km}]$ values of two Diesel vehicles (LDV4 \& LDV5) are very high, which particularly signalizes a misfunction of the SCR-system of LDV5 (LDV4 is not equipped with SCR). The specific emissions in warm-up are sometimes higher than in the urban phase with the "increase factor" ranging between $0.9 \& 7.5$ for gasoline and $0.9 \& 5$ for Diesel vehicles. 
The nanoparticle emissions PN are efficiently eliminated by the DPF's - all investigated Diesel vehicles were equipped with a filter. In the "gasoline" group, the PN-data were available only for the LDV2, which was equipped with GPF. This GPF enables the urban PN-emission to be reduced below the limit value $\left(6 \times 10^{11} \# / \mathrm{km}\right)$. For the shorter warm-up phases, the emission peak of the cold start gets more weight and the distance driven is shorter. The filtration quality of this GPF, comparing to the DPF's is quite weak and the high specific PN-emission over the warm-up gets high above the limit value.

Similar experiences exist at AFHB from the previous research on GPF's [25, 26]: the PN-emissions of a gasoline car (sometimes also with PFI) can reach $10^{13} \# / \mathrm{km}$ in WLTC $_{\text {cold. }}$ The particle count filtration efficiency of the investigated GPF's could be as low as $70 \%-80 \%$ in WLTC, in opposition to DPF's. With this knowledge the authors suggest that the non-measured PN-values of the other two gasoline vehicles could be in average of this "urban" phase at least in the range of $10^{13} \mathrm{\#} / \mathrm{km}$.

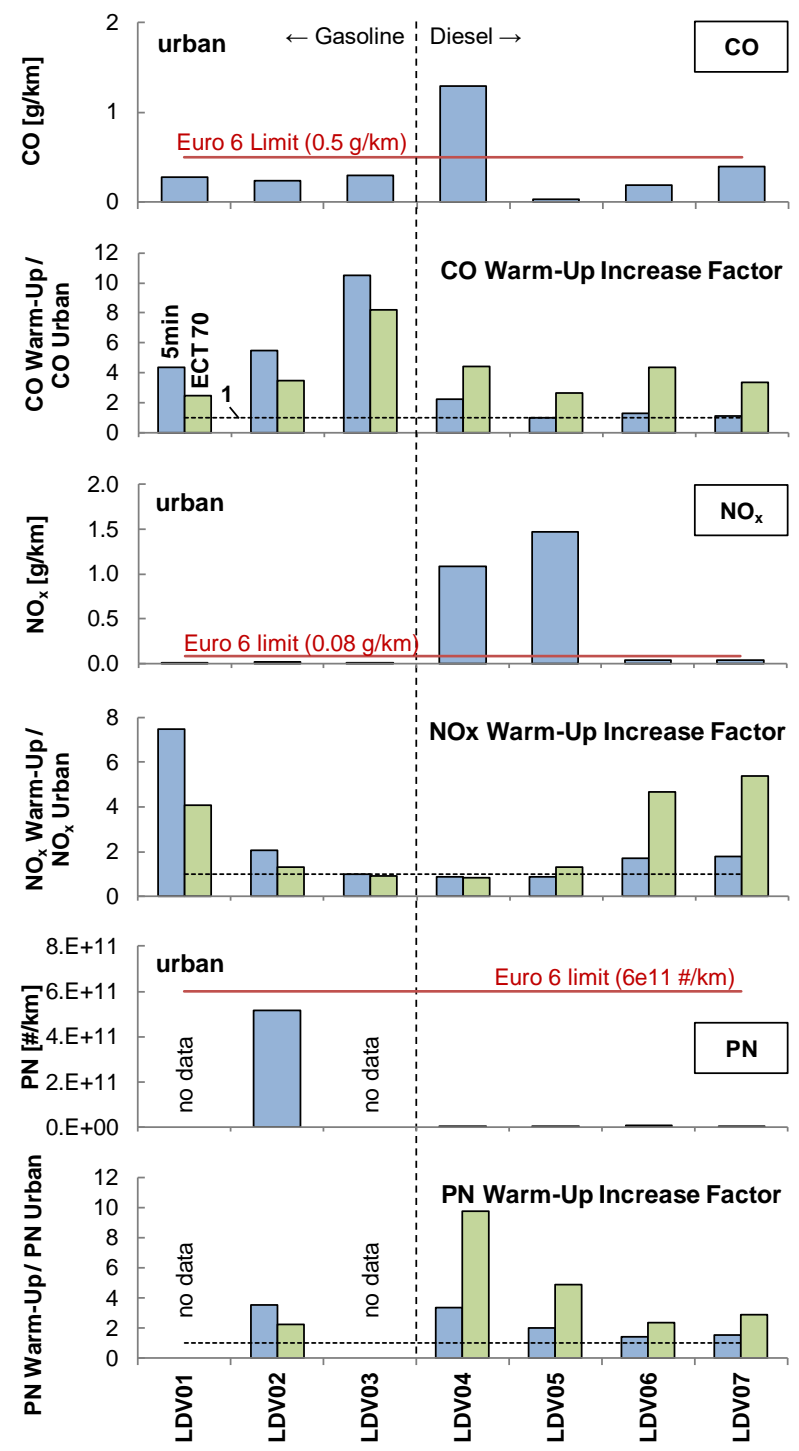

Fig. 9. Specific emissions and their increase factors in the warm-up phase
The PN warm-up increase factors for gasoline vehicle are between $2 \& 4$ (regarding both definitions of warm-up) and for Diesel vehicles these increase factors are between $1.5 \& 10$. This means that even the DPF's with the best filtration quality allow a certain penetration of the cold start $\mathrm{PN}$-emission peak, of course at an absolute very low emission level.

\subsection{Stop\&go}

The cumulated emissions in stop\&go phases are summarized for all vehicles in Fig. 10.

The comparison of emissions of the single vehicles offers a similar picture, as in the previous Fig. 9.

- in the "gasoline" group: $\mathrm{CO}_{2}$-emission is higher for bigger engines (engine swept volume increases from LDV1 to LDV3); CO-value is the highest for LDV3, which shows the slowest warm-up (see Fig. 5); the PNvalues are only given for LDV2 (equipped with GPF) and they confirm the mediocre filtration quality comparing to DPF's.

- in the "Diesel" group: high CO for LDV4 (insufficiency of engine, or of DOC); high $\mathrm{NO}_{\mathrm{x}}$ for LDV4 (no SCR) and for LDV5 (inadequacy of SCR); near-to-zero PNemissions, thanks to right-quality DPF's.

An interesting finding is given by the higher $\mathrm{CO}$ - and $\mathrm{NO}_{\mathrm{x}}$-emissions of LDV7 relatively to LDV6. Both vehicles have the same engine displacement volume and nearly identical exhaust aftertreatment systems (DOC, DPF, SCR). LDV7 was driven with its start-stop-control switched on.

This means that during the stop\&go operation, the engine was stopped and started independently on the drivers wish.

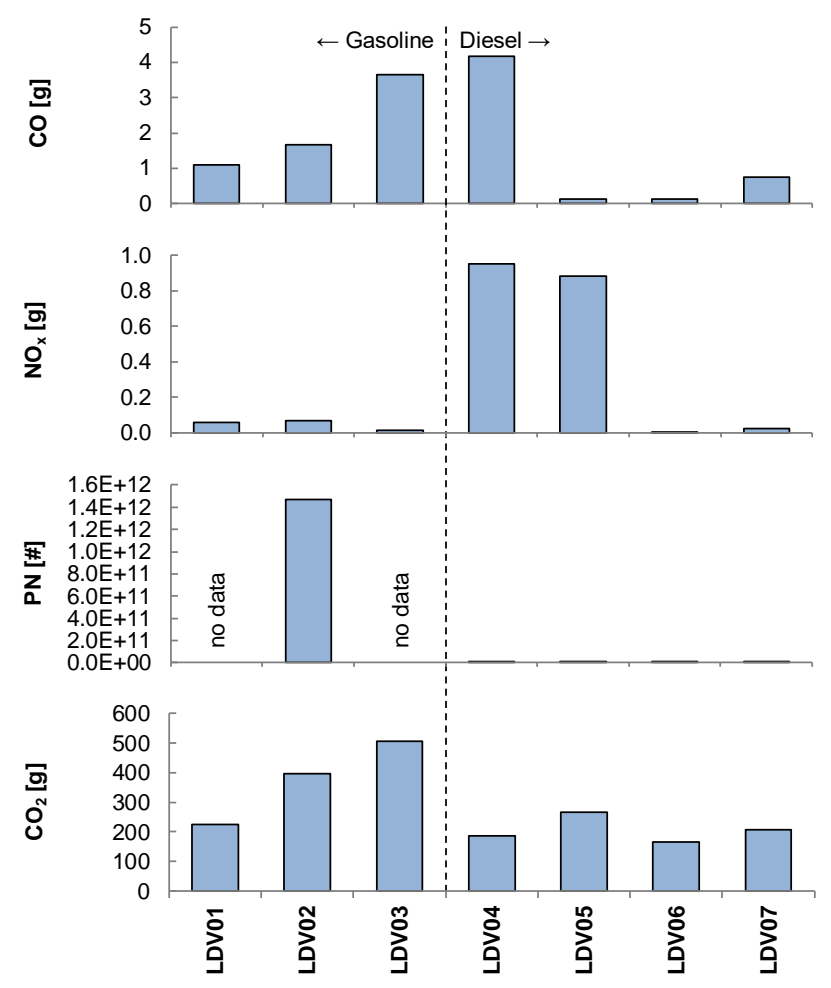

Fig. 10. Cumulated emissions in stop\&go

By engine stop, there are no emissions produced, but by engine start, there is always an emission peak. The balance 
between the emission saving and emission over-producing depends on how long is the stop-time and how intense is the start-peak. The last one depends strongly on the thermal condition of the engine and of the exhaust system. In the present urban part (first $13.7 \mathrm{~km}$ ) several start-stops must have been performed with not entirely warm exhaust aftertreatment system and the higher emission peaks at engine restart overweighed the emissions results of LDV7.

Relatively to the urban part $(13.7 \mathrm{~km})$ the cumulated emissions in stop\&go are increased/decreased by the following factors:

for gasoline vehicles:

for Diesel vehicles:

$\begin{array}{llll}\mathrm{CO} & 2-6 & \mathrm{CO} & 0.2-2.2 \\ \mathrm{NO}_{x} & 0.7-2.5 & \mathrm{NO}_{x} & 0.1-0.4 \\ \mathrm{PN} & 1.7(1 \text { vehicle }) & \mathrm{PN} & 0.4-2.3 \\ \mathrm{CO}_{2} & 0.5-0.7 & \mathrm{CO}_{2} & 0.3-0.6\end{array}$

\subsection{Idling}

Figure 11 represents the cumulated emissions at idling for all investigated vehicles. The relationships between the vehicles and the technical explanations are similar as in the previous section for "stop\&go".

Relatively to the urban part $(13.7 \mathrm{~km})$ the cumulated emissions at idling are mostly decreased with the following factors:

for gasoline vehicles:

for Diesel vehicles:

$\mathrm{CO} \quad 0.5-2.5$

CO $0.1-0.9$

$\mathrm{NO}_{\mathrm{x}} \quad 0.3-1.1$

$\mathrm{NO}_{x} \quad 0.1-0.4$

$\mathrm{PN} \quad 0.7$ (1 vehicle)

$\mathrm{PN} \quad 0.5-1.8$

$\mathrm{CO}_{2} \quad 0.3-0.6$

$\mathrm{CO}_{2} \quad 0.3-0.4$

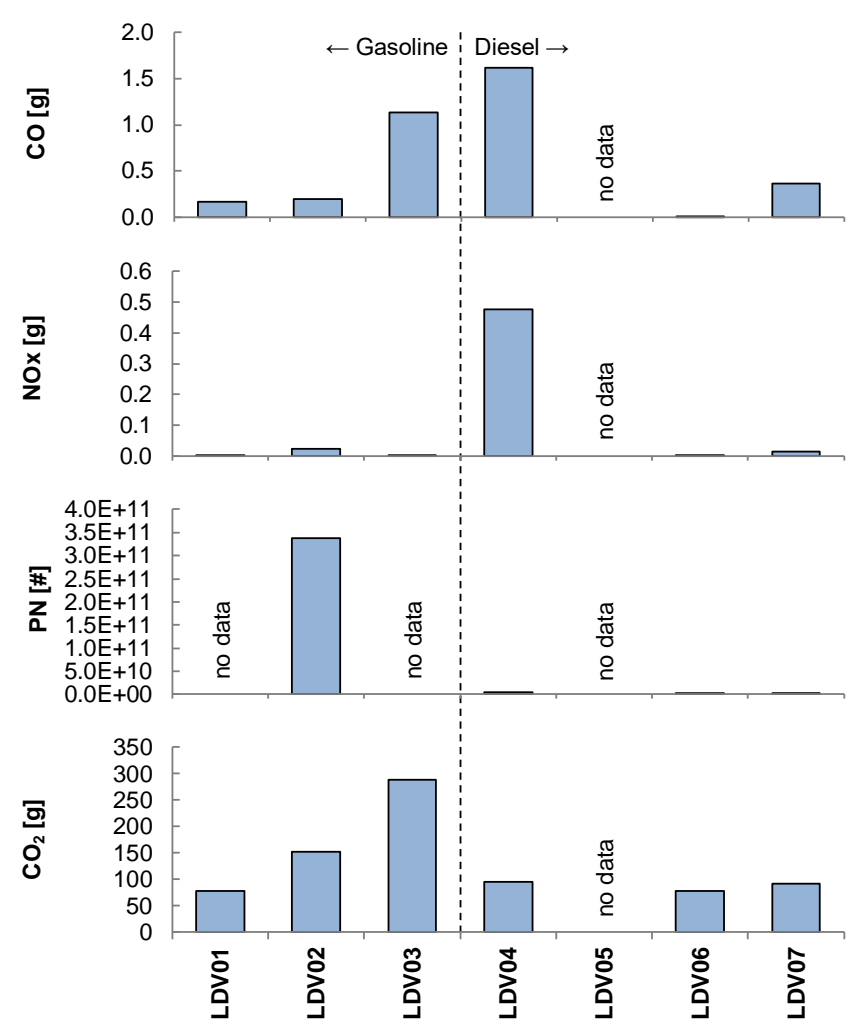

Fig. 11. Cumulated emissions at idling

\section{Reproduction of non-driving situations (part 2)}

\subsection{Test vehicles, fuels and lubricants}

The vehicles used for reproduction of special (non) driving situations are listed in the Table 2 .

All vehicles were operated with the Swiss market fuels and with the lubricating oils, which actually were present in each vehicle.

Table 2. List of vehicles used for reproduction of non-driving situations on chassis dynamometer (ga - gasoline, di - Diesel)

\begin{tabular}{|c|c|c|c|c|c|c|}
\hline Vehicle & $\begin{array}{l}\text { Instru- } \\
\text { ments }\end{array}$ & Fuel & $\begin{array}{l}\text { Displa- } \\
\text { cement }\end{array}$ & $\begin{array}{l}\text { Emis- } \\
\text { sion } \\
\text { Standard }\end{array}$ & $\begin{array}{l}\text { Exhaust } \\
\text { Aftert- } \\
\text { reatment } \\
\text { System }\end{array}$ & $\begin{array}{l}\text { Injec- } \\
\text { tion }\end{array}$ \\
\hline $\begin{array}{l}\text { ga1 - } \\
\text { "modern" }\end{array}$ & cvs & Gasoline & 1.6 & Euro 5 & TWC & GDI \\
\hline $\begin{array}{l}\text { ga1 - } \\
\text { "modern" }\end{array}$ & pems & Gasoline & 1.6 & Euro 5 & TWC & GDI \\
\hline $\begin{array}{l}\text { ga2 - } \\
\text { "dated" }\end{array}$ & cvs & Gasoline & 1.6 & Euro 3 & TWC & MPI \\
\hline $\begin{array}{l}\text { di1 - } \\
\text { "modern" }\end{array}$ & cvs & Diesel & 2.1 & Euro 6 & $\begin{array}{l}\text { DOC, DPF, } \\
\text { SCR }\end{array}$ & DI \\
\hline $\begin{array}{l}\text { di1 - } \\
\text { "modern" }\end{array}$ & pems & Diesel & 2.1 & Euro 6 & $\begin{array}{l}\text { DOC, DPF, } \\
\text { SCR }\end{array}$ & DI \\
\hline $\begin{array}{l}\text { di } 2- \\
\text { "dated" }\end{array}$ & cvs & Diesel & 2.0 & Euro 2 & DOC & DI \\
\hline
\end{tabular}

\subsection{Test installations and procedures}

\section{Chassis dynamometer test cell}

The tests were performed on the 4WD-chassis dynamometer of AFHB (Laboratory for Exhaust Emission Control of the Bern University of Applied Sciences, Biel, $\mathrm{CH}$ ).

The stationary system for regulated exhaust gas emissions is considered as reference. This equipment fulfils the requirements of the Swiss and European exhaust gas legislation.

The regulated gaseous components are measured with exhaust gas measuring system Horiba MEXA-7200; CO, $\mathrm{CO}_{2}$ - infrared analysers (IR); $\mathrm{HC}_{\mathrm{FID}}$ - flame ionization detector for total hydrocarbons; $\mathrm{CH}_{4 \mathrm{FID}}$ - flame ionization detector with catalyst for only $\mathrm{CH}_{4} ; \mathrm{NO} / \mathrm{NO}_{\mathrm{X}}-$ chemiluminescence analyzer (CLA).

The dilution ratio DF in the CVS-dilution tunnel is variable and can be controlled by means of the $\mathrm{CO}_{2}$-analysis.

The measurements of summary particle counts in the size range $23-1000 \mathrm{~nm}$ were performed with the CPC TSI 3790 (according to PMP).

For the exhaust gas sampling and conditioning a ViPR system (ViPR - volatile particle remover) from Matter Aerosol was used. This system contains:

- Primary dilution - MD19 tunable rotating disk diluter (Matter Eng. MD19-2E),

- Secondary dilution - dilution of the primary diluted and thermally conditioned sample gas on the outlet of evaporative tube,

- Thermoconditioner (TC) - sample heating at $300^{\circ} \mathrm{C}$.

\section{GAS PEMS and PN PEMS}

An information about the used Horiba Gas PEMS and about the gas measuring installation of the chassis dynamometer is given in Table 3.

As PN PEMS for Real Driving Emissions Horiba OBSONE PN measurement system (OBS-PN) was used. This analyzer works on the condensation particles counter (CPC) 
principle, has an integrated sample conditioning system (double dilution and catalytic stripper ViPR, $350^{\circ} \mathrm{C}$ ) and it indicates the summary PN concentrations in the size range 23 to approximately $1000 \mathrm{~nm}$. This system was used in the tests with the newer vehicles. It presents several advantages like compactness, robustness, fast on-line response and is recognized for legal testing purposes.

Table 3. Data of the used measuring systems

\begin{tabular}{|c|c|c|}
\hline & $\begin{array}{c}\text { HORIBA } \\
\text { MEXA } 7200\end{array}$ & $\begin{array}{l}\text { HORIBA } \\
\text { OBS ONE }\end{array}$ \\
\hline & $\begin{array}{c}4 \times 4 \text { chassis dyno } \\
\text { CVS }\end{array}$ & $\begin{array}{l}\text { PEMS (1) } \\
\text { wet }\end{array}$ \\
\hline $\mathrm{CO}$ & NDIR & heated NDIR \\
\hline $\mathrm{CO}_{2}$ & NDIR & heated NDIR \\
\hline $\mathrm{NO}_{\mathrm{x}}$ & CLD & CLD \\
\hline NO & CLD & CLD \\
\hline $\mathrm{NO}_{2}$ & calculated & calculated \\
\hline $\mathrm{O}_{2}$ & - & - \\
\hline $\mathrm{HC}$ & FID & - \\
\hline PN & not measured & - \\
\hline OBD logger & - & yes \\
\hline GPS logger & - & yes \\
\hline ambient (p, T, H) & yes & yes \\
\hline EFM & - & pitot tube \\
\hline
\end{tabular}

\section{Driving cycles on chassis dynamometer}

The vehicles were tested on a chassis dynamometer in special, simplified driving cycles, which made possible to perform different warm-up procedures, and stop\&go with different share of idling, Fig. 12. The braking resistances were set according to the legal prescriptions and responded to the horizontal road.

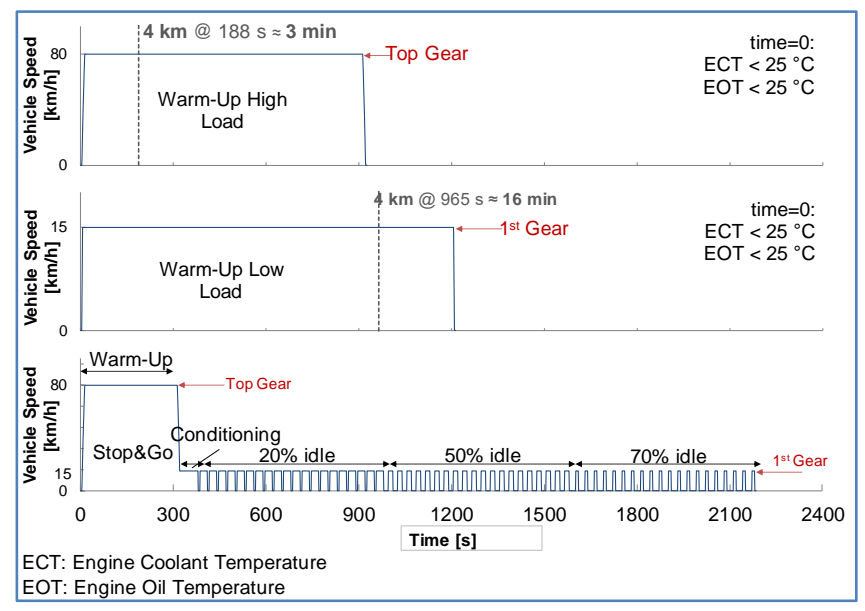

Fig. 12. Driving cycles for reproduction of warm-up and stop\&go procedures on chassis dynamometer

\section{Results}

Figure 13 shows the cumulated emissions in the first four minutes after the cold start $\left(25^{\circ} \mathrm{C}\right)$ with two gasoline vehicles. The newer (modern) vehicle is equipped with the engine and exhaust aftertreatment technology Euro 5 (with
GDI, TWC) and the older vehicle (dated) responds to the emission class Euro 3 (with MPI, TWC). "High load" means, that after the cold start, the vehicle was driven at 80 $\mathrm{km} / \mathrm{h}$ and "low load" means the same with $15 \mathrm{~km} / \mathrm{h}$ (see Fig. 12).
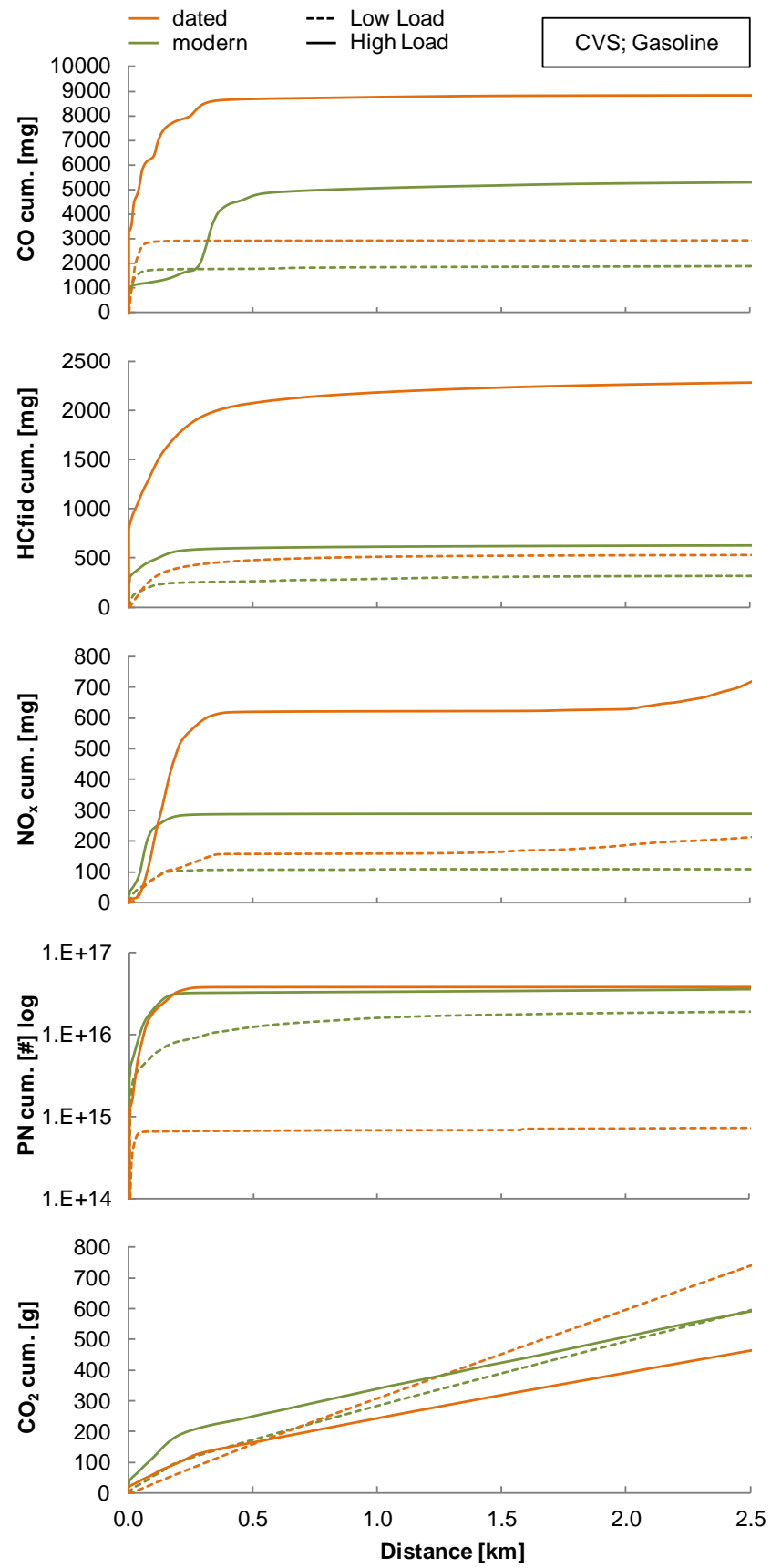

Fig. 13. Cumulated emissions during warm-up on chassis dynamometer with two gasoline vehicles and different loads

Several findings have to be mentioned:

- the emissions of $\mathrm{CO}, \mathrm{HC}, \mathrm{NO}_{\mathrm{x}}$ and $\mathrm{PN}$ are generally higher for the older vehicle and, for both vehicles, these emissions are higher with higher load,

- the majority of these emissions is cumulated in the first $0.5 \mathrm{~km}$ of distance approximately; exception is $\mathrm{NO}_{\mathrm{x}}$ of the dated vehicle: after $2 \mathrm{~km} \mathrm{NO}_{\mathrm{x}}$ starts to increase, es- 
pecially with "high load" indicating some draw-back of the catalytic reduction,

- the emission traces obtained with PEMS (for the modern vehicle) are in a very good accordance with the emissions from the laboratory installation (CVS),

- the PN-emissions of the dated vehicle (MPI) at high load are identical with the emissions of the modern vehicle (GDI); this confirms the high PN-emissions potential of the MPI fleet as well,

- the nearly linear increase of cumulated $\mathrm{CO}_{2}$-emissions is connected to the fuel consumption of vehicles, the relationships of slopes are influenced by the fact, that this representation is given over the driving distance and responds to different operating time. The distance of $2.5 \mathrm{~km}$ means for $80 \mathrm{~km} / \mathrm{h} 1.9$ minutes and for 15 $\mathrm{km} / \mathrm{h} 10$ minutes of driving.

Figure 14 represents the cumulated emissions for the Diesel vehicles. "Dated" means Euro 2 (DOC) and modern means Euro 6 (DOC, DPF, SCR). The remarkable findings are:

- the emissions of $\mathrm{CO}, \mathrm{HC}, \mathrm{NO}_{\mathrm{x}}$ and $\mathrm{PN}$ are generally higher for the older vehicle, the emissions of $\mathrm{CO}, \mathrm{HC}$, and for the older vehicle, also $\mathrm{NO}_{\mathrm{x}}$, are higher with lower load (inversely to gasoline vehicles),

- the emissions of $\mathrm{CO}, \mathrm{HC}$ and $\mathrm{NO}_{\mathrm{x}}$ for the older vehicle, and particularly at low load, are cumulated not only at cold start but also in the entire represented time slot until $4 \mathrm{~km}$ distance driven,

- the PN-emissions of both vehicles are cumulated mainly during the cold start:

- for the older vehicle they are significantly higher than for the newer one (up to 6 orders of magnitude) and are independent of the load,

- for the newer vehicle (with DPF) the PN-values at low load are lower than at high load due to the lower penetration of the cold start emission peak,

- the emission traces obtained with PEMS (for the modern vehicle) are in a very good accordance with the emissions from the laboratory installation (CVS),

- the nearly linear increase of cumulated $\mathrm{CO}_{2}$-emissions is connected to the fuel consumption of vehicles, the differences of slopes for low- and high load result from the representation of results over the distance and not over the time (see remarks to Fig. 13).

The tests of the stop\&go operation with varying portion of idling were performed with warm engine and warm exhaust aftertreatment system. As a consequence, the measured emission values were very low. The exception is the older Diesel vehicle, which was equipped with a quite aged DOC only. The higher emissions which result from this vehicle allow to remark much better the effects of the idling rate.

Figure 15 represents, as example the emissions of this vehicle per distance and per time in function of the percentage of idling.

The answer to the question: how does the share of idling influence the emissions in the stop\&go operation? - finally depends on the representation (consideration) over the distance or over the time. With increasing portion of idling the distance-specific emission (per $\mathrm{km}$ ) increase and the timespecific emissions (per min) decrease.
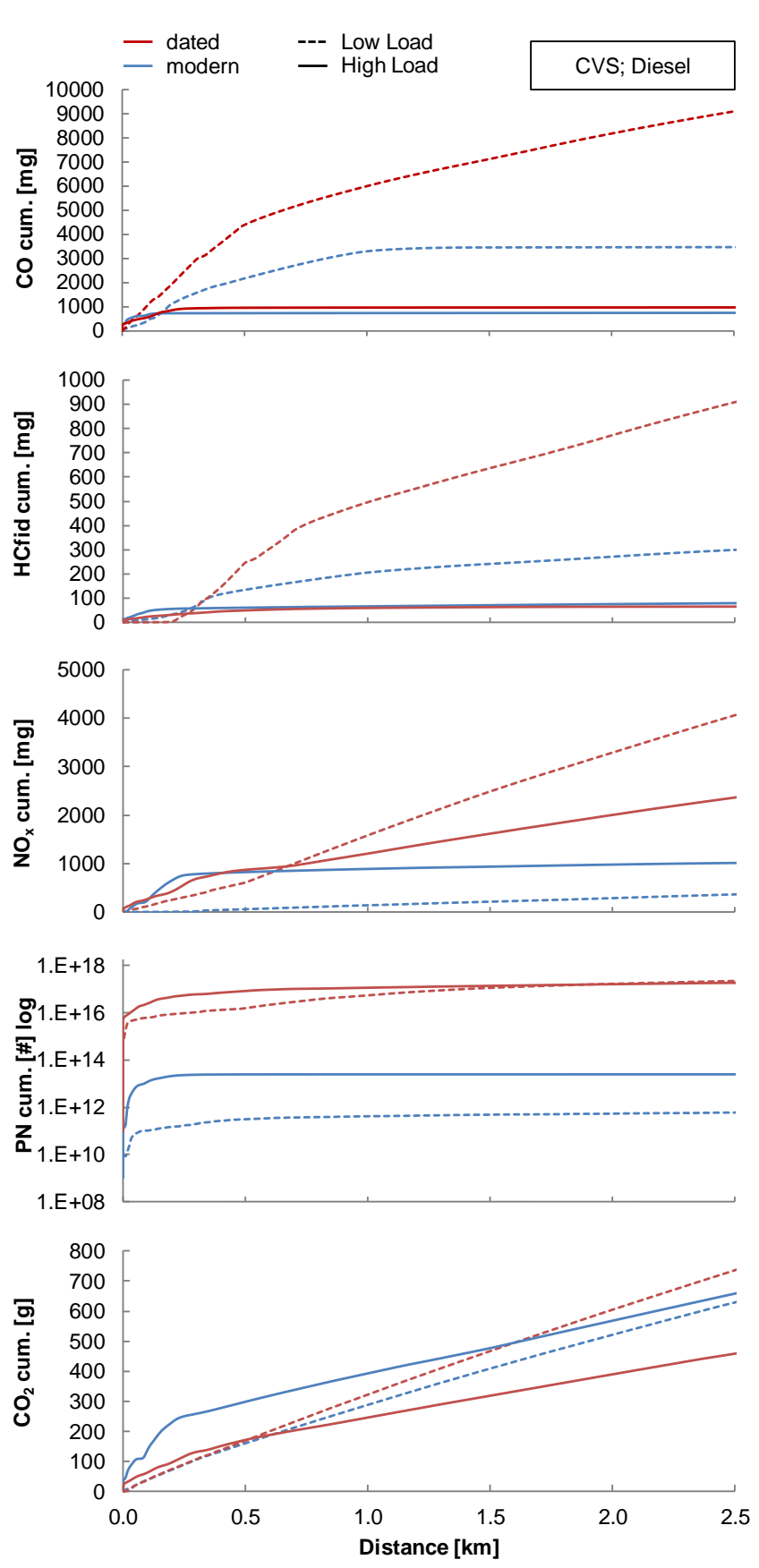

Fig. 14. Cumulated emissions during warm-up on chassis dynamometer with two Diesel vehicles and different loads

\section{Conclusion}

\subsection{Analysis of present data}

For research of emissions from non-driving or special driving situations the RDE data of 7 vehicles (3 gasoline and 4 Diesel) were analyzed.

The first $13.7 \mathrm{~km}$ of distance after cold start were defined as "urban" part and definitions of: warm-up (including start), "stop\&go" and idling, were established in order to enable the automatic evaluation.

The most important conclusions from this research are:

- the emissions of $\mathrm{CO}, \mathrm{NO}_{\mathrm{x}}$ and $\mathrm{PN}$ are in the cold start and in the first part of the warm-up phase (c.a. 25s) considerably higher, than in the rest of the investigated urban phase (HC-data were not available), 

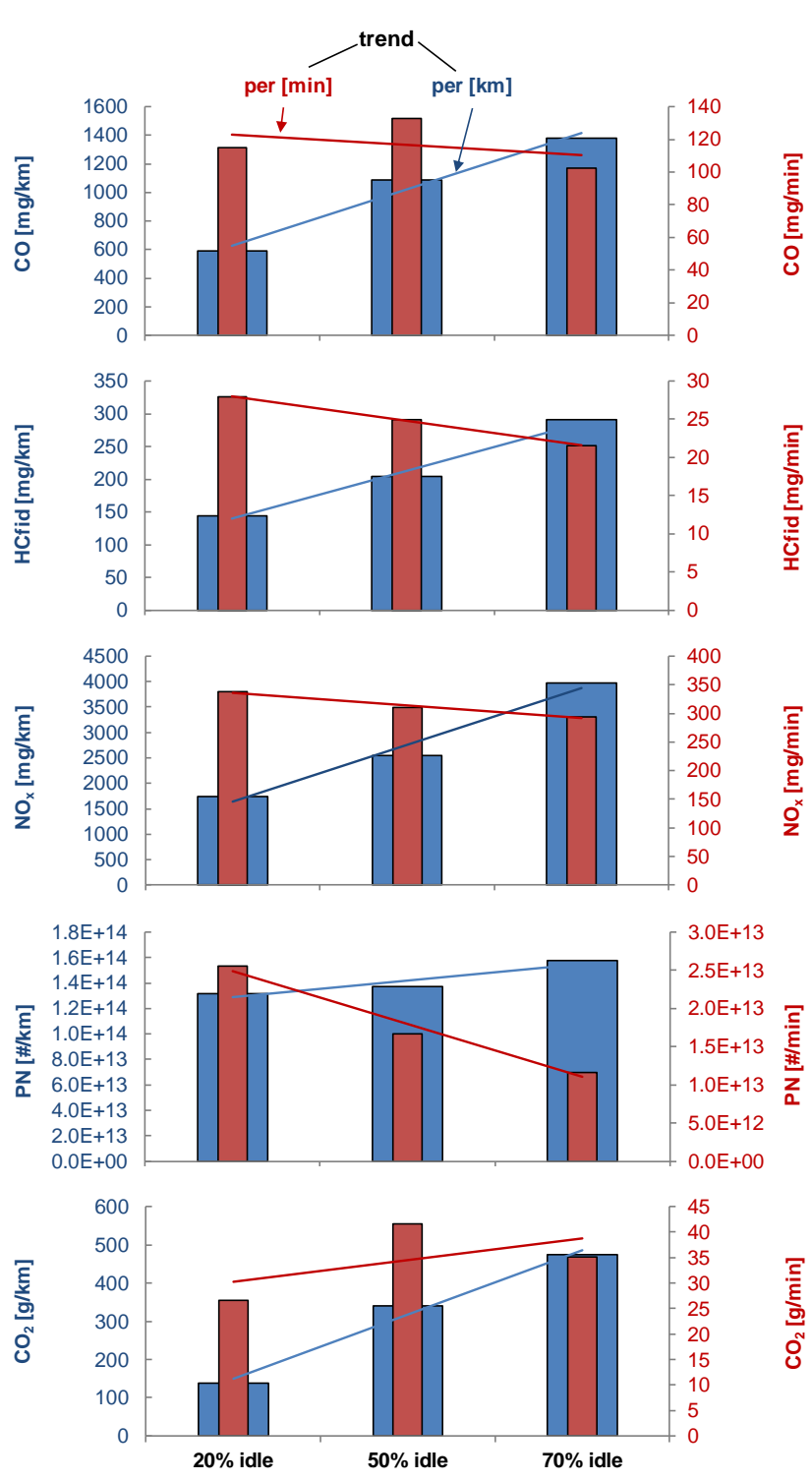

Fig. 15. Emissions of the older Diesel vehicle in the stop\&go cycle depending on the share of idling; representations as distance-, and timespecific

- the special emitting situations: "stop\&go" and idling are frequently given during the warm-up phase, i.e. with engine and exhaust treatment system not warm enough,

- vehicles with smaller engine displacement have lower cumulated $\mathrm{CO}_{2}$-emissions (lower fuel consumption), they are tendentially quicker to be warmed-up,
- in both vehicles' groups: "gasoline" and "Diesel" there are quite considerable emissions differences between the vehicles, resulting mostly from different efficiencies of the exhaust aftertreatment systems,

- the specific emissions [in $\mathrm{g} / \mathrm{km}$ ] are in the warm-up generally significantly higher than in the investigated urban phase $(13.7 \mathrm{~km})$; the respective "increase factors" are in average: for $\mathrm{CO} 6$; for $\mathrm{NO}_{\mathrm{x}} 4$; for $\mathrm{PN} 6$,

- the GPF, which was applied on one of the investigated gasoline vehicles showed a weak filtration quality comparing to the DPF's which were used on the Diesel vehicles,

- the start-stop-system switched on during the warm-up is tendentially disadvantageous because the cold exhaust aftertreatment system cannot eliminate sufficiently the emissions peaks produced by restarting the engine.

\subsection{Reproduction of non-driving situations}

The non-driving (or special driving) situations - warmup with different engine load and stop\&go with different portions of idling - were reproduced on a chassis dynamometer with two gasoline vehicles and two Diesel vehicles. Both vehicles types were represented by a newer and an older technology.

During the cold start and warm-up in the first $2.5 \mathrm{~km}$, the emissions of older type vehicles are generally higher than for the newer technology. The majority of emissions are accumulated in the first $0.5 \mathrm{~km}$ of the distance driven.

The PN-level of older technology gasoline vehicle (MPI) at higher load $(80 \mathrm{~km} / \mathrm{h})$ is equal to the PN-level of the newer technology (GDI) - both vehicles without GPF.

The advantages and the efficiency of the modern Diesel aftertreatment (DPF) are confirmed by a significant reduction of PN.

In the stop\&go operation, there are several tendencies of increasing the specific emissions $[\mathrm{mg} / \mathrm{km}]$ with the higher share of idling (except of: HC for gasoline vehicles and PN for all vehicles). One of the factors taken into consideration is the shorter distance driven with the higher portion of idling in the tested time interval. The consideration of emissions per time $[\mathrm{mg} / \mathrm{min}]$ results in lowering most of the emissions with higher portion of idling.

\section{Acknowledgements}

The authors express gratitude to the Swiss Federal Offices for Environment (BAFU) for the financial support of these activities.

\section{Nomenclature}

$\begin{array}{ll}\text { AFHB } & \text { Abgasprüfstelle FH Biel, CH } \\ \text { ASTRA } & \text { Federal Office of Roads } \\ \text { CF } & \text { Conformity Factor } \\ \text { CLD } & \text { Chemoluminescence Detector } \\ \text { DI } & \text { Direct Injection } \\ \text { DOC } & \text { Diesel Oxidation Catalyst } \\ \text { DPF } & \text { Diesel Particle Filter } \\ \text { ECT } & \text { Engine Coolant Temperature } \\ \text { EFM } & \text { Exhaust Flow Meter } \\ \text { EMPA } & \text { Eidgenössische Material-Prüfanstalt }\end{array}$

EMROAD Data processing reference software

EOT Engine Oil Temperature

Es Engine Start

EU European Union

FID Flame Ionization Detector

FOEN Federal Office of Environment, $\mathrm{CH}$

GPF Gasoline particulate filter

GPS Global Positioning System

HD Heavy Duty

HDV Heavy Duty Vehicles 


\begin{tabular}{llll}
\hline ISC & In-Service Conformity & RDE & Real Driving Emission \\
LD & Light Duty & ResRDE & research of RDE \\
LDV & Light Duty Vehicles & SCR & Selective Catalytic Reduction \\
NDIR & Non-Dispersive Infrared & TA & Type Approval \\
OBD & On Board Diagnosis & TPA & Tailpipe Attachment \\
OCE & Off-Cycle Emissions & TWC & Three-way catalyst \\
PEMS & Portable Emissions measurement system & V & vehicle \\
PFI & port fuel injection & WHTC & World Heavy-Duty Transient Cycle \\
PN & Particle Number & WLTC & World Light-Duty Transient Cycle
\end{tabular}

\section{Bibliography}

[1] European Environment Agency. EMEP/EEA Air pollutant emission inventory guidebook 2016. EEA Report. 2016, 21. https://www.eea.europa.eu//publications/emep-eeaguidebook-2016 (accessed on 29 March 2019).

[2] FRANCO, V., KOUSOULIDOU, M., MUNTEAN, M. et al. Road vehicle emission factors development: a review. Atmosphere Environment. 2013, 70, 84-97. https://doi.org/10.1016/j.atmosenv.2013.01.006

[3] NTZIACHRISTOS, L., GKATZOFLIAS, D., KOURIDIS, C. et al. COPERT: A European road transport emission inventory model. In: Athanasiadis, I.N., Rizzoli, A.E., Mitkas, P.A., Gómez J.M. (eds) Information Technologies in Environmental Engineering. Environmental Science and Engineering. Springer, Berlin, Heidelberg. https://doi.org/10.1007/978-3-540-88351-7_37

[4] BORGE, R., LUMBRERAS, J., PEREZ, J. et al. Emission inventories and modeling requirements for the development of air quality plans. Application to Madrid (Spain). Science of the Total Environment. 2014, 466-467, 809-819. https://doi.org/10.1016/j.scitotenv.2013.07.093

[5] VAlVERDE, V., MORA, B.A., ClAIROTTE, M. et al. Emission factors derived from 13 Euro 6b light-duty vehicles based on laboratory and on-road measurements. Atmosphere. 2019, 10, 243.

https://doi.org/10.3390/atmos10050243

[6] GIECHASKIEL, B., GIORIA, R., CARRIERO, M. et al. Emission factors of a Euro VI heavy-duty diesel refuse collection vehicle. Sustainability. 2019, 11, 1067. https://doi.org/10.3390/su11041067

[7] ANDERSSON, J., MAY, J., FAVRE, C. et al. On-road and chassis dynamometer evaluations of emissions from two Euro 6 diesel vehicles. SAE International Journal of Fuels and Lubricants. 2014, 7(3), 919-934. https://doi.org/10.4271/2014-01-2826.

[8] BIELACZYC, P., WOODBURN, J., SZCZOTKA, A. Exhaust emissions of gaseous and solid pollutants measured over the NEDC, FTP-75 and WLTC chassis dynamometer driving cycles. SAE Technical Paper 2016-011008. 2016. https://doi.org/10.4271/2016-01-1008

[9] MAY, J., BOSTEELS, D., FAVRE, C. An assessment of emissions from light-duty vehicles using PEMS and chassis dynamometer testing. SAE International Journal of Engines. 2014, 7(3), 1326-1335. https://doi.org/10.4271/2014-01-1581

[10] CLAIROTTE, M., VALVERDE, V., BONNEL, P. et al. Joint Research Centre 2018, Light-duty vehicles emissions testing. Publications Office of the European Union. Luxembourg, 2018. https://doi.org/10.2760/289100

[11] CZERWINSKI, J., ZIMMERLI, Y., COMTE, P. et al. Experiences and results with different PEMS. TAP Paper. International Transport and Air Pollution Conference, May 24th-26th, 2016, Lyon.

[12] CZERWINSKI, J., ZIMMERLI, Y., COMTE, P. et al. Potentials of the portable emission measuring systems (PN

PEMS) to control real driving emissions (RDE). 38. International Vienna Motor Symposium, 27-28 April 2017, VDI Fortschritt-Bericht. 2017, 12(802), Vol. 2.

[13] CZERWINSKI, J., COMTE, P., ZIMMERLI, Y. et al. Research of emissions with gas PEMS and PN PEMS. TAP Paper, International Transport and Air Pollution Conference, $15^{\text {th }}-16^{\text {th }}$ November 2017, EMPA, Zürich.

[14] GIECHASKIEL, B., ROCCOBONO, F., BONNEL, P. Feasibility study on the extension of the Real Driving Emissions (RDE) procedure to particle number (PN). European Commission. Joint Research Centre. 2016. https://doi.org/10.2790/74218

[15] SUAREZ-BERTOA, R., VALVERDE, V., CLAIROTTE, $M$. et al. On-road emissions of passenger cars beyond the boundary conditions of the real-driving emissions test. Environmental Research. 2019, 176, 108572. https://doi.org/10.1016/j.envres.2019.108572

[16] O'DRISCOLL, R., STETTLER, M.E.J., MOLDEN, N. et al. Real world $\mathrm{CO}_{2}$ and $\mathrm{NO}_{\mathrm{x}}$ emissions from 149 Euro 5 and 6 diesel, gasoline and hybrid passenger cars. Science of the Total Environment. 2018, 621, 282-290. https://doi.org/10.1016/j.scitotenv.2017.11.271

[17] LUJÁN, J.M., BERMÚDEZ, V., DOLZ, V. et al. An assessment of the real-world driving gaseous emissions from a Euro 6 light-duty diesel vehicle using a portable emissions measurement system (PEMS). Atmospheric Environment. 2018, 174, 112-121.

https://doi.org/10.1016/j.atmosenv.2017.11.056

[18] KO, J., MYUNG, C.L., PARK, S. Impacts of ambient temperature, DPF regeneration, and traffic congestion on $\mathrm{NO}_{\mathrm{x}}$ emissions from a Euro 6-compliant diesel vehicle equipped with an LNT under real-world driving conditions. Atmospheric Environment. 2019, 200, 1-14. https://doi.org/10.1016/j.atmosenv.2018.11.029

[19] KAWAI, T., TSUNOOKA, T., CHIBA, F. et al. Effect of high concentration ethanol on SI engine cold startabillity and emissions. 16. Aachener Kolloquium Fahrzeug- und Motorentechnik. 2007, 2, 1075.

[20] CZERWINSKI, J., COMTE, P., ENGELMANN, D. et al. Non-legislated emissions and PN of two passenger cars with gasoline-butanol blends. Combustion Engines. 2018, 172(1), 64-72. https://doi.org/10.19206/CE-2018-108

[21] STEPIEN, Z., CZERWINSKI, J. Cold start with ethanolblend fuels and influences on non-legislated emissions of a GDI flex fuel vehicle. Polish Journal of Environmental Studies. 2017, 26(5), 2223-2229.

https://doi.org/10.15244/pjoes/69282.

[22] CZERWINSKI, J., COMTE, P., GÜDEL, M. Nonlegislated emissions of a GDI flex fuel passenger car at cold start with ethanol and butanol blend fuels. TAE. 11th International Colloquium Fuels Conventional and Future Energy for Automobiles. 2017, 199-207.

[23] BIELACZYC, P., WOODBURN, J., SZCZOTKA, A. An Investigation into cold start emissions from compression 
ignition engines using EU legislative emissions test procedures. SAE International Journal of Fuels and Lubricants. 2013, 6(2), 466-477.

https://doi.org/10.4271/2013-01-1304

[24] BIELACZYC, P., SZCZOTKA, A., WOODBURN, J. The effect of a low ambient temperature on the cold-start emissions and fuel consumption of passenger cars. Proceedings of the Institution of Mechanical Engineers, Part D: Journal of Automobile Engineering. 2011, 225(9), 1253-1264.

https://doi.org/10.1177/0954407011406613

Danilo Engelmann - Professor at the University of Applied Sciences, Biel-Bienne, Switzerland.

e-mail: danilo.engelmann@bfh.ch

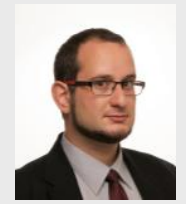

Pierre Comte, Dipl.-Ing. HTL - University of Applied Sciences, Biel-Bienne, Switzerland.

e-mail:pierre.comte@bfh.ch
[25] CZERWINSKI, J., COMTE, P., HEEB, N. et al. Nanoparticle emissions of DI gasoline cars with/without GPF. SAE Technical Paper 2017-01-1004. 2017. https://doi.org/10.4271/2017-01-1004.

[26] CZERWINSKI, J., COMTE, P., ENGELMANN, D. et al. PN-emissions of gasoline cars MPI and potentials of GPF. SAE Technical Paper 2018-01-0363. 2018. https://doi.org/10.4271/2018-01-0363

Andreas Hüssy, BSc., BFH Automotive Engineering University of Applied Sciences, Biel-Bienne, Switzerland

e-mail: andreas.huessy@bfh.ch

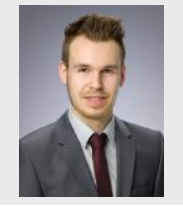

Jan Czerwinski, Prof. Dr. - Professor Emeritus at the University of Applied Sciences, Biel-Bienne,

Switzerland, CJ Consulting.

e-mail: cjcons19@gmail.com

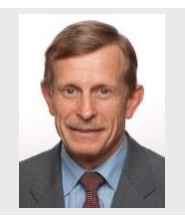

Peter Bonsack, MSc., ME. - Federal Office for the Environment FOEN, Bern, Switzerland.

e-mail: peter.bonsack@bafu.admin.ch 